Review

\title{
The development and application of catalysts for ultra-deep hydrodesulfurization of diesel
}

\author{
FANG Xiangchen ${ }^{\mathrm{a}, \mathrm{b}, *}$, GUO Rong ${ }^{\mathrm{a}, \mathrm{b}}$, YANG Chengmin ${ }^{\mathrm{a}}$ \\ a Fushun Research Institute of Petroleum and Petrochemicals, SINOPEC, Fushun 113001, Liaoning, China \\ b State Key Laboratory of Chemical Engineering, East China University of Science and Technology, Shanghai 200237, China
}

\section{A R T I C L E I N F O}

\section{Article history:}

Received 12 October 2012

Accepted 14 December 2012

Published 20 January 2013

\section{Keywords:}

Ultra-deep hydrodesulfurization

Catalyst preparation

Reaction environment

Thermal dynamic equilibrium

Catalyst stacking

\begin{abstract}
A B S T R A C T
The history and current status of research concerning preparation and application technology for diesel ultra-deep hydrodesulfurization (HDS) catalysts were summarized. As a result of systematic research aimed at understanding the fundamental mechanism of ultra-deep HDS catalysis, various technology for the preparation of HDS catalysts have been developed, including novel alumina supports, as well as methods for tuning the surface properties of catalysts and otherwise modifying these materials so as to improve alkyl transfer performance. The result of these improvements is that a number of ultra-deep HDS catalysts with excellent performance, such as FHUDS-5 and FHUDS-6, have been developed. In addition, parallel research work investigating the interactions between different types of HDS catalysts and different hydrotreatment reactor zones has developed stacked catalyst technology that allows for the optimization of catalytic performance, so as to meet the demands of commercial production facilities for ultra-low-sulfur diesel.
\end{abstract}

(C) 2013, Dalian Institute of Chemical Physics, Chinese Academy of Sciences. Published by Elsevier B.V. All rights reserved.

\section{Introduction}

As a consequence of the ongoing demand for improvements in fuel quality, the development and application of ultra-deep hydrodesulfurization (HDS) catalysts for diesel has in recent years become the focus of a significant number of studies [1-6]. To meet the emission requirements of the China National IV and Euro V standards, three technology platforms were established since 2005 based on a combination of basic research and the development of new techniques of catalyst preparation. These technologies include novel catalyst supports suitable for HDS of high molecular weight sulfides, control of the surface properties of metal supports, and reaction route adjustments intended to improve the performance of ascension alkyl transfer desulfurization and the optimization of catalyst stacking. One aspect of this ongoing technological improvement has been the development and successful application, in more than 30 industrial units worldwide, of a series of high-performance diesel HDS catalysts consisting of FH-UDS, FHUDS-2, FHUDS-3, FHUDS-5, and FHUDS-6 [7]. The results of these commercial applications have demonstrated that the FHUDS-5 and FHUDS-6 catalysts exhibit particularly strong performance when applied to ultra-deep HDS, such that FHUDS-5 became the first SINOPEC's catalyst for the long-term production of ultra-low-sulfur diesel overseas. This paper focuses primarily on summarizing the history and current status of the various technologies developed for diesel ultra-deep HDS catalysis.

\section{Preparation of novel support materials}

SINOPEC has abundant practical experience in the research and design of HDS catalysts, and has in the past developed a series of catalysts for hydrotreating distillates. These catalysts, however, were not fully satisfactory in terms of their ability to

\footnotetext{
* Corresponding author. Tel: +86-24-56409575; Fax: +86-24-56429551; E-mail: fangxiangchen.fshy@sinopec.com DOI: $10.1016 / \mathrm{S} 1872-2067(11) 60506-8$
} 
promote diesel ultra-deep HDS. A significant amount of research work has shown that the most important aspect of sulfur removal via diesel ultra-deep HDS is the extraction of high molecular weight sulfides such as 4,6-DMDBT [1-6,8]. The removal of 4,6-DMDBT is problematic since the methyl substituents on the aromatic rings on either side of the molecule hinder the access of the sulfur atom to the catalyst's active sites. To mitigate this problem, catalysts with improved hydrogenation activity are required to reduce the saturation of the aromatic rings. Another factor that affects the removal of sulfur compounds is molecular diameter, which is generally significantly greater in the case of sulfide molecules with more complex structures, and which requires specific tailoring of the pore size distribution of the catalyst support materials [9]. The molecular diameters of thiophene, 4-MDBT, and 4,6-DMDBT, for instance, are $0.445,0.648$, and $0.877 \mathrm{~nm}$, respectively. As such, depending on which of these is to be removed, there will be specific requirements with regard to the support's pore sizes. Since the ultra-deep HDS of diesel requires removal of high molecular weight sulfides such as 4,6-DMDBT, the requirements for the catalyst support for this process will be different than the requirements associated with the production of low-sulfur diesel with $350 \mu \mathrm{g} / \mathrm{g}$ sulfur.

Many studies have shown that in addition to the need for supports with high specific surface areas and large pore volumes, there are other support characteristics that must also be considered $[10,11]$. Alumina is the main component of these supports, and it has been determined that supports in which the alumina has a high degree of crystallinity exhibit better activity for HDS, a phenomenon that is attributed to the presence of more active metal anchoring sites on highly crystalline supports [12]. Figure 1(a) illustrates the relationship between the degree of crystallinity of alumina supports and the acid content of the material.

Both the mean pore size and the pore size distribution of supports have significant effects on the molecular diffusion aspect of the catalytic reaction. Figure 1(b) shows the relationships between pore diameter and both specific surface area and molecular diffusion (as evaluated by the catalyst's effective use factor for naphthalene). Figure 1(c) presents the relationship between pore distribution concentration and the tortuosity factor of the support pores. The pore distribution concen-

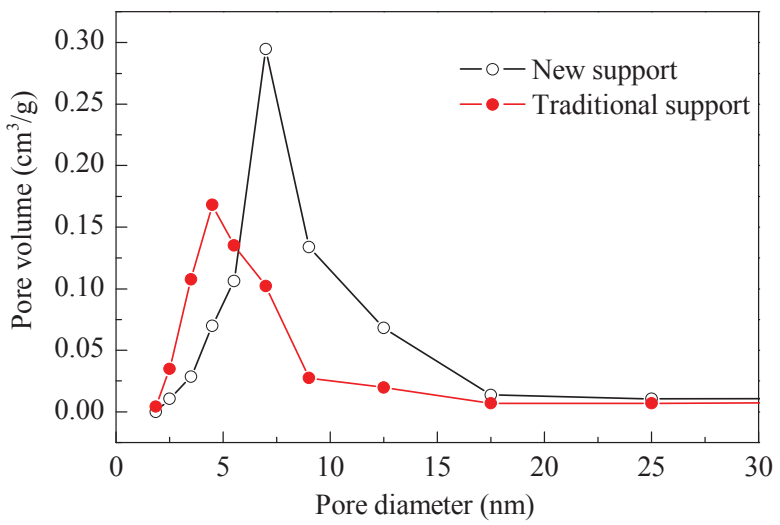

Fig. 2. Pore size distribution curves of new and traditional alumina support.

tration is calculated as the ratio of the pore volume contributed by the mean pore size $\pm 3 \mathrm{~nm}$ to the total pore volume, while the tortuosity factor is calculated as the ratio of the measured benzene diffusion factor to the theoretical calculated diffusion value assuming straight, cylindrical pores.

As a result of the optimization of the synthetic process and associated aging conditions, pseudo-boehmite has been synthetized with aluminum sulfate/sodium aluminate to produce a novel alumina with an increased degree of crystallinity and higher acid content. This material has subsequently been employed as an alumina support to create a series of new catalysts with higher specific surface areas and higher pore distribution concentrations, as well as larger and more accessible pores. The differences in the pore size distributions between these new supports and the traditional catalytic materials are shown in Fig. 2. The acid properties of these support surfaces have been characterized using two probe molecules of differing molecular diameter; ammonia $(0.26 \mathrm{~nm})$ and pyridine $(0.65 \mathrm{~nm})$, and the results are presented in Table 1.

As can be seen from Table 1, there are no significant differences in acid content between the two supports based on the $\mathrm{NH}_{3}$-TPD results. However, the pyridine-TPD data indicate that the weak acid and medium strength acid contents of the new support are much higher than those of the old support. This suggests that the pore size and channel structures of the new support are well matched with the anticipated reactant mole-
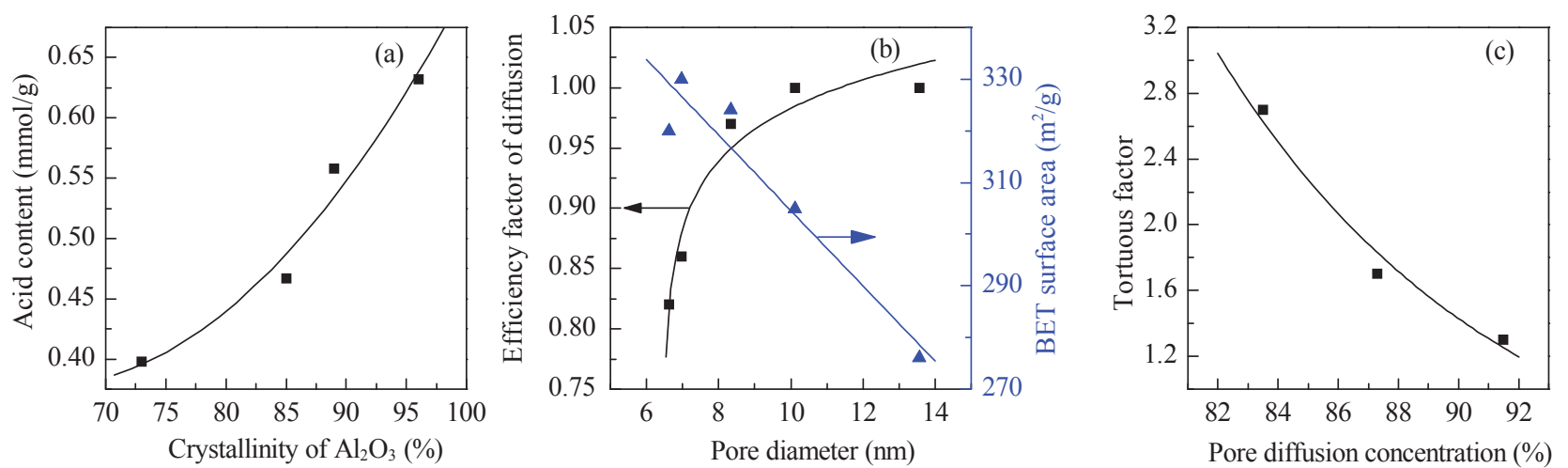

Fig. 1. Relationship between alumina support crystallinity and acid content (a), support pore diameter and both diffusion and specific surface area (b), and pore distribution concentration and support tortuosity (c). 
Table 1

Acid properties of new and traditional alumina supports.

\begin{tabular}{lccccc}
\hline \multirow{2}{*}{ Support } & \multicolumn{3}{c}{$\begin{array}{c}\text { Pyridine-TPD acid content } \\
(\mathrm{mmol} / \mathrm{g})\end{array}$} & $\begin{array}{c}\mathrm{NH}_{3} \text {-TPD } \\
\text { acid content } \\
\text { (mmol/g) }\end{array}$ \\
\cline { 2 - 5 } Traditional & 0.203 & 0.355 & 0 & 0.558 & 0.643 \\
New & 0.228 & 0.405 & 0 & 0.633 & 0.654 \\
\hline
\end{tabular}

cules, especially with regard to allowing the diffusion of larger molecules. Both its increased quantity of active sites and its larger pore sizes make this new material a suitable candidate for the HDS of high molecular weight sulfides such as 4,6-DMDBT.

The FH-UDS catalyst was developed based on the new support technology described above. This catalyst has demonstrated high HDS activity and has consequently been widely and successfully applied in many industrial processing operations.

\section{Technology for the tuning of the surface properties of metal supports}

The main reaction sequence in the hydrodesulfurization of 4,6-DMDBT begins with the hydrogenation of the aromatic ring structures, followed by scission of the $\mathrm{C}-\mathrm{S}$ bond, allowing removal of the sulfur. Consequently, HDS catalysts must exhibit suitable performance with regard to hydrogenation, especially when treating feedstocks with high final boiling points, since these contain a greater proportion of both polyaromatic hydrocarbons and 4,6-DMDBT.

To further improve the activity of ultra-deep HDS catalysts, the relationship between the surface properties of the supports and the hydrogenation activity of the catalyst's active metal was studied. The resulting data showed that, during the synthesis of HDS catalysts, the rate of metal deposition and the interactions between the metal and the support were affected by the electronic and chemical surface properties of the support as well as the physical and chemical properties of the impregnation liquid. These factors were also found to affect the sulfidation of the active metal and the sulfided metal valence, as well as the extent of dispersion and stability of the metal [13].

Based on further systematic research, methods of adjusting the interactions between metal and support to control the catalyst's surfaces properties were developed. These modified preparation methods work to weaken the interactions between metal and support through the addition of an organic chelating agent.

Table 2 summarizes the X-ray photoelectron spectroscopy (XPS) data obtained for a sulfided Mo-Co type catalyst prepared in this manner (B) as well as a catalyst prepared by the conventional method $(\mathrm{A})$.

Table 2

XPS data for two different sulfided catalysts.

\begin{tabular}{|c|c|c|c|c|c|}
\hline \multirow{2}{*}{ Catalyst } & \multirow{2}{*}{$\begin{array}{l}\mathrm{Mo}^{4+} /\left(\mathrm{Mo}^{4+}+\mathrm{Mo}^{5+}\right. \\
\left.+\mathrm{Mo}^{6+}\right) \text { ratio }(\%)\end{array}$} & \multirow{2}{*}{ S/Mo } & \multicolumn{2}{|c|}{ Binding energy $(\mathrm{eV})$} & \multirow{2}{*}{$\begin{array}{c}\text { Sulfidation } \\
(\%)\end{array}$} \\
\hline & & & $\mathrm{Mo}^{4+} 3 d_{5 / 2}$ & Co $2 p_{3 / 2}$ & \\
\hline A & 65.88 & 1.70 & 228.8 & 780.1 & 73.6 \\
\hline B & 75.03 & 1.78 & 228.6 & 778.4 & 87.0 \\
\hline
\end{tabular}

It is evident from Table 2 that the metal-support interactions of catalyst B are weakened, such that catalyst B was more readily sulfided (with a $10 \%$ increase in sulfidation) and has a higher proportion of $\mathrm{Mo}^{4+}$ relative to catalyst $\mathrm{A}$.

Further work along these lines led to the development of the W-Mo-Ni type catalyst FHUDS-2, which exhibits high hydrogenation activity, and the Mo-Co type catalyst FHUDS-3, which is highly active for HDS. FHUDS-3 has been used for a significant length of time in a $0.78 \mathrm{Mt} / \mathrm{a}$ diesel hydrotreating unit operated by IOCL in India for the producting diesel with sulfur content $<50 \mu \mathrm{g} / \mathrm{g}$ and FHUDS-2 has been used in many commercial diesel hydrotreating units in China.

The hydrogenation activities of both FHUDS-2 and FHUDS-3 were improved by adjusting the surface properties of the catalysts to meet the requirements of industrial units to produce China National IV diesel, as well as to produce diesel with sulfur content below $10 \mu \mathrm{g} / \mathrm{g}$. However, under severe processing conditions such as high space velocities, high reaction temperatures, and low reaction pressures, even these catalysts do not completely remove refractory sulfides such as 4,6-DMDBT, since the extent of the hydrogenation reaction under such conditions is restricted by thermodynamic factors.

\section{Technologies for eliminating steric hindrance in HDS through improved alkyl transfer activity}

There are three reaction routes for the removal of 4,6-DMDBT from fuel, these being the hydrogenation, direct hydrogenolysis and alkyl transfer desulfurization routes. The particular reaction route depends on the feed properties, liquid space velocity and reaction pressure. If the main route is hydrogenation, a Ni-Mo catalyst is recommended, whereas for direct hydrogenolysis, a Co-Mo catalyst is employed prior to the Ni-Mo. The HDS route has the advantages of higher reaction activity and lower product density, although hydrogen consumption is relatively high and the reaction efficiency may be limited by the thermodynamic equilibrium. The direct desulfurization approach results in lower hydrogen consumption and can be operated at a higher weight average bed temperature (WABT), but it may be severely affected by steric hindrance factors. The alkyl transfer route becomes the most effective approach for the desulfurization of refractory sulfides such as 4,6-DMDBT when the hydrogenation approach is hindered at high WABT levels. The influences of steric hindrance can be effectively eliminated through the application of this route.

One method for improving alkyl transfer reactivity is to increase the acid content of the HDS catalyst, especially the Brönsted acid content. However, the catalyst components typically used to increase acid content, such as zeolites, also increase the dry gas yield and hydrogen consumption, both of which are unfavorable for diesel HDS. For this reason, the Brönsted acid content of the FHUDS-5 (Mo-Co) and FHUDS-6 (Mo-Ni) catalysts are instead increased by incorporating appropriate organic and inorganic additives to improve catalyst acidity.

The Brönsted acid content and the ratio of Brönsted to Lewis acids of FHUDS-5 and a reference catalyst are presented in 
Table 3

Brönsted acid properties of catalysts.

\begin{tabular}{lccccccc}
\hline \multirow{2}{*}{ Catalyst } & \multicolumn{3}{c}{$\begin{array}{c}\text { Pyridine-TPD Brönsted acid } \\
\text { content }(\mathrm{mmol} / \mathrm{g})\end{array}$} & & \multicolumn{2}{c}{$\mathrm{B} / \mathrm{L}$ ratio* } & \multirow{2}{*}{$(\%)$} \\
\cline { 2 - 4 } \cline { 6 - 7 } & Total & $<250{ }^{\circ} \mathrm{C}$ & $>250{ }^{\circ} \mathrm{C}$ & & $<250{ }^{\circ} \mathrm{C}$ & $>250{ }^{\circ} \mathrm{C}$ \\
\hline FHUDS-5 & 0.139 & 0.042 & 0.097 & & 28.0 & 38.0 \\
Reference & 0.044 & 0.002 & 0.042 & & 1.4 & 14.1 \\
\hline
\end{tabular}

* Ratio of Brönsted to Lewis acid content.

Table 3. Using dimethylbenzene mixed with $1.43 \%$-xylene as a feedstock, the alkyl transfer performance of FHUDS-5 was studied by following the changes in $p$-xylene content at different reaction temperatures, with the results shown in Table 4.

Table 3 shows that both the Brønsted acid content and the ratio of Brönsted to Lewis acids in FHUDS-5 are significantly higher than in the reference catalyst. If $<250{ }^{\circ} \mathrm{C}$ acids are defined as weak and the $>250{ }^{\circ} \mathrm{C}$ acids are defined as medium and strong, it can be seen that medium and strong Brönsted acid content and Brönsted to Lowies acid ratio of FHUDS-5 are significantly increased. The result is that this catalyst exhibits improved performance with regard to alkyl transfer at high temperatures, and thus is better suited to the removal of sulfur in the form of 4,6-DMDBT via alkyl transfer.

The data in Table 4 demonstrates that the alkyl transfer performance of FHUDS-5 improves with increases in reaction temperature. The reaction temperature of a hydrotreating unit in the middle and at the end of a run producing ULSD is typically high, and the catalyst load in the reactor bottom also normally operates at higher temperature. Under these conditions, the hydrogenation reaction method is normally limited by thermodynamic factors, whereas the alkyl transfer process resulting from the use of FHUDS-5 at high temperature can not only effectively eliminate the steric hindrance effect, but also reduce the influence of high temperature thermodynamic equilibrium limitations, resulting in more efficient removal of the sulfur present as 4,6-DMDBT.

Figure 3 compares the performance of FHUDS- 5 with that of the most recent and most widely used Mo-Co type HDS catalyst. These plots show that FHUDS-5 demonstrates significant advantages when applied to the production of ULSD under high temperature and lower pressure process conditions, which can be attributed to its improved capacity for alkyl transfer reactions.

Figure 4 summarizes the improvements in the reaction activity of the FHUDS series of catalysts related to the production of ULSD with a sulfur content less than $10 \mu \mathrm{g} / \mathrm{g}$. It can be seen that both the Mo-Co type catalyst FHUDS- 5 and the Mo-Ni type FHUDS- 6 have greatly improved performance. As a result of this improved performance, FHUDS- 5 was able to pass performance tests carried out by Norwegian STATOIL, BP, MOL Hun-

\section{Table 4}

Feedstock $p$-xylene content after hydrotreatment with FHUDS-5 catalyst.

\begin{tabular}{lc}
\hline Reaction temperature $\left({ }^{\circ} \mathrm{C}\right)$ & $p$-Xylene $(\%)$ \\
\hline 340 & 2.00 \\
380 & 4.02 \\
400 & 5.82 \\
430 & 8.83 \\
\hline
\end{tabular}

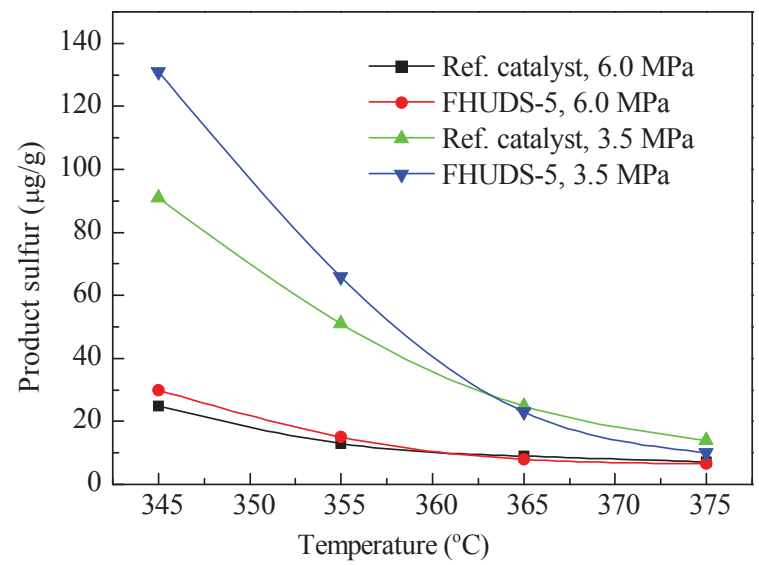

Fig. 3. Performance of FHUDS-5 and a reference catalyst under ultra-deep HDS conditions.

gary, and other oil companies between 2010 and 2011, and was recognized as a high-performance catalyst. Also, in April 2011, FHUDS-5 was selected in an open bidding process as the catalyst for a European ULSD production facility. Results obtained from the application of this catalyst in commercial production have shown that its activity and stability are superior to those of catalysts previously employed for this purpose.

\section{Effect of reaction environment on diesel ultra-deep desulfurization}

Research activities concerning HDS, as well as knowledge gained during their commercial application, have demonstrated that performance of a catalyst when producing ULSD is affected by many factors that must be taken into account, including the nitrogen content of the feedstock and thermodynamic equilibrium limiting effects at high temperature. Reducing the negative effects of the reaction environment can promote the efficient operation of a hydrotreating unit and result in stable production of ULSD.

Many research results have indicated that the presence of organic nitrogen compounds strongly inhibits the HDS reaction, with the extent of this inhibitory effect dependent on both the type and concentration of the nitrogen compounds. Table 5

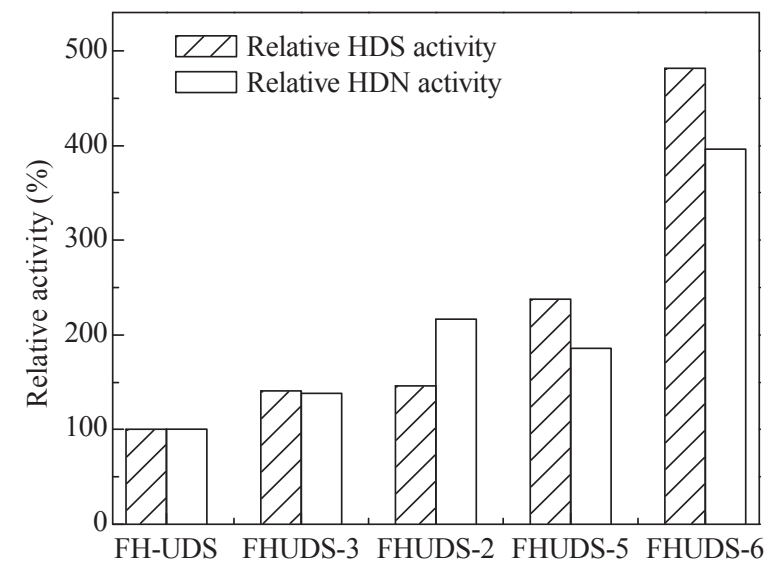

Fig. 4. HDS and HDN activity of ultra-deep desulfurization catalysts. 
Table 5

Influence of pyridine content on DBT and 4,6-DMDBT reaction routes.

\begin{tabular}{lccccc}
\hline $\begin{array}{l}\text { Pyridine content } \\
(\mu \mathrm{g} / \mathrm{g})\end{array}$ & \multicolumn{2}{c}{ DBT reaction route (\%) } & & \multicolumn{2}{c}{$\begin{array}{c}4,6-\text { DMDBT reaction } \\
\text { route }(\%)\end{array}$} \\
\cline { 2 - 3 } \cline { 5 - 6 } \cline { 5 - 6 } & DDS & HYD & & DDS & HYD \\
\hline 50 & 78 & 22 & & 20 & 80 \\
100 & 82 & 18 & & 25 & 75 \\
200 & 85 & 15 & & 32 & 68 \\
400 & 90 & 10 & & 34 & 66 \\
\hline
\end{tabular}

presents reaction routes obtained for the DBT and 4,6-DMDBT using pyridine as a standard nitrogen compound, under conditions consisting of $4.0 \mathrm{MPa}$ pressure, $3.0 \mathrm{~h}^{-1} \mathrm{LHSV}$, and $340{ }^{\circ} \mathrm{C}$. These data indicates that increasing concentrations of the nitrogen compound suppress the hydrogenation route. The effect of high nitrogen content on DDS is relatively less, but it obviously inhibits the HYD reaction route of 4,6-DMDBT . The effect of the nitrogen compound on the HYD route is less evident when the nitrogen compound content is less than $100 \mu \mathrm{g} / \mathrm{g}$.

Figure 5 shows the extent of polyaromatic hydrocarbons (PAHs) saturation at different process pressures and temperatures. Although the thermodynamic equilibrium temperature varies with the process pressure, these datas indicate that the PAH content increases above the thermodynamic equilibrium temperature, implying that the application of high temperatures can affect the HYD reaction route of 4,6-DMDBT and consequently reduce the effectiveness of ultra-deep HDS.

In summary, as the data presented thus far have shown, high temperature reaction processes are deleterious when ultra-deep desulfurization proceeds via the HYD route, but are favorable to desulfurization proceeding by the alkyl transfer mechanism.

The effects of the processing system $\mathrm{H}_{2} \mathrm{~S}$ content on the HDS reaction are well known: in general, higher concentrations of $\mathrm{H}_{2} \mathrm{~S}$ result in reduced catalytic activity. Low levels of $\mathrm{H}_{2} \mathrm{~S}$ have little effect on the HYD route but significantly affect the DDS route, whereas high levels of $\mathrm{H}_{2} \mathrm{~S}$ will have obvious inhibitory effects on both routes.

The particular HDS catalyst employed will have an effect on the desulfurization reaction mechanism. Typically, a Mo-Co type catalyst will function primarily via the DDS route, whereas the main reaction route of the Mo-Ni and W-Mo-Ni catalysts is

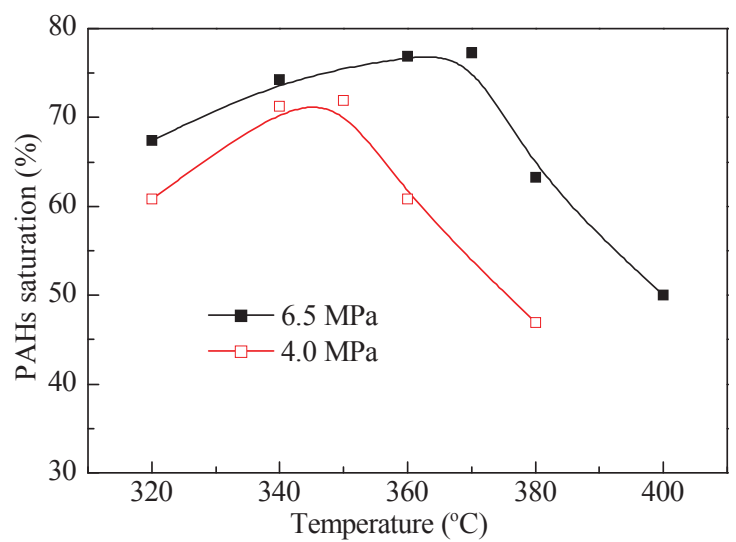

Fig. 5. Extent of polyaromatic saturation as a function of bed temperature.
HYD. Therefore, the Mo-Co type catalyst is characterized by higher DDS activity and lower hydrogen consumption when producing ULSD. In addition, it is little affected by thermodynamic equilibrium limitations, such that it can be used at higher values of WABT. The drawback associated with this type of catalyst is that its reaction efficiency is strongly influenced by steric hindrance effects, necessitating improved alkyl transfer performance to mitigate this deficit. The Mo-Ni or W-Mo-Ni type catalyst is characterized by higher HDN and HYD activity and lower product density, but has the disadvantage that the catalyst's hydrogenation performance is poor at higher temperatures and lower pressures because of thermodynamic limitations.

The selection of the most appropriate ultra-deep HDS catalyst for a specific reaction environment is therefore a challenging process that requires careful consideration. In cases where the feedstock has relatively high nitrogen and aromatic hydrocarbon contents, a catalyst with higher HYD activity should be selected, in conjunction with process conditions combining high pressure with lower LHSV and temperature. Feedstocks with higher sulfur but lower nitrogen and aromatic hydrocarbon contents, however, will be optimized by adopting a catalyst with good DDS activity under conditions of lower pressure and higher LHSV and temperature. In most cases, the reaction environment of the upper reactor bed is relatively close to the former of these two conditions, and the reaction environment of the bottom bed is closer to the latter, and so under these circumstances it is most beneficial to implement the stacking of different catalysts within the reactor.

The beneficial results of catalyst stacking on the ultra-deep HDS of straight-run diesel blends with 5\% LCO and 35\% coker distillate are shown in Table 6 . The results indicate that a synergistic effect can be obtained by adopting a practical approach to catalyst stacking in the reaction environment.

It has been determined that the activity and stability of Mo-Co type catalysts are superior to those of Mo-Ni or W-Mo-Ni type catalysts at high temperatures and low pressures. As discussed above, considering the differences between reaction zones under actual operation conditions, to allow the stable production of ULSD at high temperatures from straight-run diesel blended with secondary processing diesel containing higher sulfur and nitrogen, a catalyst with high hydrogenation activity should be used in the upper bed, since the reaction temperature in this zone will not exceed $370{ }^{\circ} \mathrm{C}$ over the course of the run. This catalyst selection will assist in obtaining the optimal levels of PAH saturation and nitrogen removal. In addition, a catalyst with high DDS and alkyl transfer

Table 6

Effects of catalyst stacking on diesel HDS.

\begin{tabular}{lccc}
\hline \multirow{2}{*}{ Catalyst } & \multicolumn{3}{c}{ Properties of products } \\
\cline { 2 - 4 } & $\begin{array}{c}\text { Sulfur } \\
(\mu \mathrm{g} / \mathrm{g})\end{array}$ & $\begin{array}{c}\text { Nitrogen } \\
(\mu \mathrm{g} / \mathrm{g})\end{array}$ & $\begin{array}{c}\text { Aromatics } \\
(\mathrm{wt} \%)\end{array}$ \\
\hline FHUDS-6 & 18.0 & 1.0 & 18.1 \\
FHUDS-5 & 37.0 & 7.0 & 20.3 \\
Stacked FHUDS-6/FHUDS-5 & 8.0 & 1.0 & 18.9 \\
\hline Reaction conditions: $360^{\circ} \mathrm{C}, 6.4 \mathrm{MPa}, 2.2 \mathrm{~h}^{-1}$. Feed: $c(\mathrm{~S})=12238 \mu \mathrm{g} / \mathrm{g}$, \\
$c(\mathrm{~N})=734 \mu \mathrm{g} / \mathrm{g}$.
\end{tabular}




\section{Graphical Abstract}

Chin. J. Catal., 2013, 34: 130-139 doi: 10.1016/S1872-2067(11)60506-8

The development and application of catalysts for ultra-deep hydrodesulfurization of diesel

FANG Xiangchen*, GUO Rong, YANG Chengmin

Fushun Research Institute of Petroleum and Petrochemicals, SINOPEC;

East China University of Science and Technology

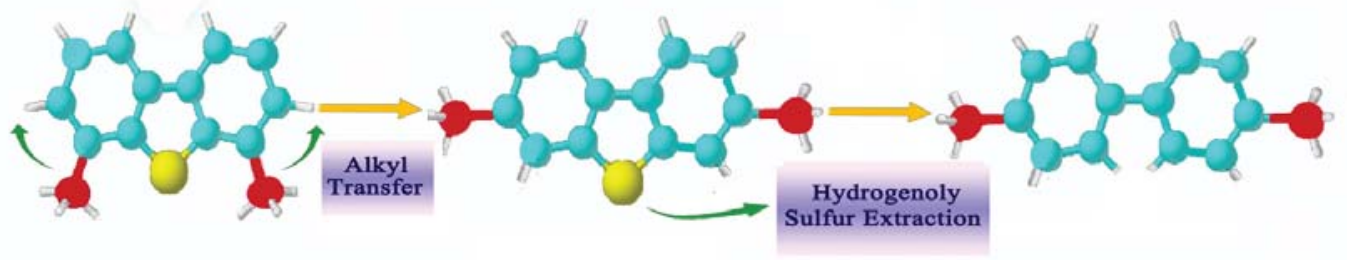

A summary of research efforts related to the design, synthesis, and application of ultra-deep hydrodesulfurization catalysts for diesel fuels is presented. Progress in the field is discussed, including the preparation of novel supports and the development of new technigues for tuning active metal surface properties, improving alkyl transfer performance and increasing the use of stacked catalysts.

activity should be loaded in the bottom bed, to mitigate the effect of thermodynamic equilibrium limitations in the middle and at the end of the run. At present, a diesel ultra-deep HDS reaction kinetics model has been established by combining a large quantity of experimental data, and consequently an optimized technology platform based on catalyst stacking has been developed. This stacking technology has been applied in four large-scale hydrotreating units operated by the Shanghai petrochemical company, the Zhenhai refining and chemical company and others, and has demonstrated good results in the production of ULSD.

\section{Conclusions}

Three main technology platforms have been established as the result of research into the processes and mechanisms of catalytic diesel ultra-deep HDS. These are: the preparation of novel catalytic support materials that promote the HDS reactions of high molecular weight sulfides, the control of the surface properties of metal supports, and the optimization of reaction routes. Based on these platforms, the catalysts FHUDS- 5 and FHUDS-6, both of which exhibit high activity for HDS, have been successfully developed and widely applied. In addition, these new technologies have established a strong foundation for the future development and improvement of hydrotreatment catalysts.

Catalyst stacking technology has been developed through additional research into reaction mechanisms, the results of which have shown that different catalysts types are required for different reaction environments. This stacking technology will enable commercial production facilities to meet the demands of producing Euro IV and V diesel, making the most efficient use of hydrotreating units and catalysts. It will also lead to improvements in feedstock adaptability and prolong the service life of hydrotreating units.
There is, however, still some room for improvement regarding these catalysts. Although the activity and stability of FHUDS-5 are superior at high temperatures, its performance at low reaction temperatures should be improved. In addition, the mechanisms underlying the metal-support interactions should be further studied, to allow additional optimization of the activity of the FHUDS series of catalysts.

\section{References}

[1] Stanislaus A, Marafi A, Rana M S. Catal Today, 2010, 153: 1

[2] Perot G. Catal Today, 2003, 86: 111

[3] Aguirre-Gutierrez A, de la Fuente J A M, de los Reyes J A, del Angel P, Vargas A J.J Mol Catal A, 2011, 346: 12

[4] Badoga S, Mouli K C, Soni K K, Dalai A K, Adjaye J. Appl Catal B, 2012, 125: 67

[5] Lam V, Li G, Song C, Chen J, Fairbridge C, Hui R, Zhang J. Fuel Process Technol, 2012, 98: 30

[6] Oyama S T, Gott T, Zhao H, Lee Y. Catal Today, 2009, 143: 94

[7] Guo R, Shen B X, Fang X Ch, Yao Y H. Petrol Refin Eng (郭蓉, 沈本 贤, 方向晨, 姚运海. 炼油技术与工程), 2011, 41(12): 31

[8] Uday T T, Ma X L, Song C S. Catal Today, 2003, 86: 265

[9] Li X, Han D Z, Xu Y Q Liu X M, Yan Z F. Mater Lett, 2011, 65: 1765

[10] Hong W, Liu B J, Wang H B, Chen Y. Chin J Catal (洪伟, 刘百军, 王 宏宾, 陈玉. 催化学报), 2012, 33: 1586

[11] Yin H L, Zhou T N, Liu Y Q, Chai Y M, Liu C G.J Nat Gas Chem, 2011, 20: 441

[12] Qiherima, Li H F, Yuan H, Zhang W H, Xu G T. Chin J Catal (齐和日 玛, 李会峰, 袁德, 张暳宏, 徐广通. 催化学报), 2011, 32: 240

[13] Liu B, Chai Y M, Wang Y J, Liu Y Q, Liu C G. J Nat Gas Chem, 2012, 21: 194

[14] Bai T Zh, Liu J H, Liu W, Song Y Y, Sun H X, Bao H Zh. Petrol Refin Eng (白天忠, 刘继华, 柳伟, 宋永一, 孙厚祥, 包洪洲. 炼油技术 与工程), 2011, 41(8): 1

[15] Shao Zh C, Gao X D, Li H G, Nie H. Acta Petrol Sin (Petrol Process Sect) (邵志才, 高晓冬, 李皓光, 聂红. 石油学报 (石油加工)), 2006, 22(4): 12 


\title{
柴油超深度加氢脱硫催化剂的开发及应用
}

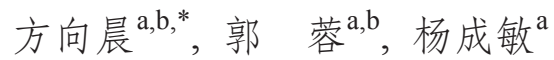 \\ ${ }^{a}$ 中国石化抚顺石油化工研究院，辽宁抚顺 113001 \\ b华东理工大学化学工程联合国家重点实验室, 上海200237
}

\begin{abstract}
摘要: 介绍了柴油超深度加氢脱硫催化剂制备及应用技术的研发过程. 通过对超深度加氢脱硫反应机理和催化基础的详细研究, 建立了催化剂的制备技术平台, 包括新型的氧化铝载体制备技术、催化剂表面控制技术和提升催化剂烷基转移性能的改性技术, 开发了FHUDS-5和FHUDS-6等性能优异的催化剂; 通过研究不同类型催化剂性能与反应器不同区域环境的特点, 建立了优化的 催化剂级配使用技术平台, 满足了工业上对超低硫柴油生产的需求.
\end{abstract}

关键词：超深度加氢脱硫; 催化剂制备; 反应环境; 热力学平衡; 催化剂级配

收稿日期: 2012-10-12. 接受日期: 2012-12-14. 出版日期: 2013-01-20.

*通讯联系人. 电话: (024)56409575; 传真: (024)56429551; 电子信箱: fangxiangchen.fshy@sinopec.com

本文的英文电子版由Elsevier出版社在ScienceDirect上出版(http://www.sciencedirect.com/science/journal/18722067).

\section{1. 前言}

随着油品质量的不断升级, 柴油超深度加氢脱硫 (HDS) 催化剂的开发和应用研究成为业内关注的重 点 ${ }^{[1 \sim 6]}$. 自2005年以来, 为了满足生产国 IV 和欧 $V$ 排放标 准低硫柴油的要求, 通过系统的应用基础研究和催化剂 制备技术的开发, 建立了适合大分子硫化物反应的新型 催化载体制备技术平台, 载体-活性金属表面性质控制 技术平台, 以及包括提升烷基转移脱硫性能和优化催化 剂级配使用的反应路线调节技术平台, 相继开发了 FH-UDS, FHUDS-2, FHUDS-3, FHUDS-5 及 FHUDS-6系 列高性能的柴油加氢脱硫催化剂, 并成功应用于国内外 30 多套大型柴油加氢装置上 ${ }^{[7]}$. 特别是后期开发的 FHUDS-5 和FHUDS-6等催化剂表现出很高的超深度脱 硫性能, 并实现了工业应用, 成为中国石化首个在国外 用于长周期生产超低硫柴油的HDS催化剂. 本文将在描 述柴油超深度HDS催化剂开发过程的基础上, 系统介绍 催化剂制备技术平台和应用技术平台的开发情况.

\section{2. 适合柴油超深度脱硫催化剂的载体技术平台 的开发}

中国石化具有丰富的开发HDS催化剂的实践经验, 开发了一系列的馏分油加氢精制催化剂, 但用于柴油超 深度HDS时, 其性能尚有待于提高. 大量的研究表明, 柴 油超深度加氢脱硫的关键是脱除柴油中所含的 4,6-二甲 基二苯并噻吩 (4,6-DMDBT) 类大分子硫化物 ${ }^{[1-6,8]}$. 4,6-DMDBT类硫化物分子结构分析表明, 甲基取代基位 阻效应阻碍了硫原子与活性中心的可接触性, 需要催化 剂有更高的加氢活性, 通过对芳烃的饱和以克服该位阻
效应的不利影响; 另一方面, 随着硫化物分子结构的复 杂化, 分子直径显著增加, 对载体孔道的要求更高 ${ }^{[9]}$. 例 如, 噻吩、4-甲基噻吩和4,6-DMDBT的分子直径依次是 $0.445,0.648$ 和 $0.877 \mathrm{~nm}$. 与生产低硫柴油 $(\mathrm{S}<350 \mu \mathrm{g} / \mathrm{g})$ 相比, 柴油超深度脱硫时需要脱除4,6-DMDBT类硫化 物, 因而对载体的要求与早期的催化剂载体不同.

大量的应用基础研究表明, 除了要求载体具有大的 比表面积和孔体积外, 还应关注其他性质 ${ }^{[10,11]}$. 作为催 化剂活性中心担载体的载体, 氧化铝的结晶度越高, 其 催化剂性能越好. 这是由于结晶度高的氧化铝具有更多 的用于针定金属的活性中心位 ${ }^{[12]}$. 如图1(a)所示, 氧化 铝酸量随着其结晶度的增加而增加. 另外, 载体的平均 孔径和孔分布对反应分子扩散的影响很大. 图1(b)为载 体平均孔径与反应物分子扩散速度及载体比表面积之 间的关系. 这里分子扩散的情况用荎分子对催化剂的有 效利用系数予以表征. 图1(c)给出了孔分布集中度与载 体孔的曲折因子之间的关系. 其中孔的集中度用催化剂 最可几孔径 $\pm 3 \mathrm{~nm}$ 范围的孔体积占总孔体积的比例来计 算; 曲折因子是以测定的苯分子扩散系数与在同孔径圆 柱型直孔道的理论计算值的比值来表征.

在上述工作的基础上, 结合 4,6-DMDBT的结构和反 应途径, 采用硫酸铝-偏铝酸钠法合成拟薄水铝石, 通过 合成、老化等条件的优化, 制得了结晶度高且酸量增加 的新型氧化铝载体材料, 从而开发了孔体积大、比表面 积高、孔径较大、孔分布集中、孔道更畅通的新型氧化 铝载体平台. 新型载体与FH-DS催化剂载体孔结构的差 异见图2.

分别采用分子直径差别较大的氨(临界直径 0.26 $\mathrm{nm}$ )和吡啶(临界直径 $0.65 \mathrm{~nm}$ ) 作为吸附质来表征这二个 
载体的表面酸性质特征, 结果列于表1. 由表1可见, 老载 体及新型载体的 $\mathrm{NH}_{3}$-TPD吸附酸量无明显差异, 但新型 载体的吡啶-TPD吸附酸量中, 弱酸和中等强度的酸量明 显高于老载体. 这表明新型载体的孔径及孔道结构有利 于反应物分子, 特别是较大分子的扩散和有效的反应活 性中心数增加, 从而有利于 $4,6-\mathrm{DMDBT}$ 类大分子硫化物 的加氢脱硫反应进行.

在上述新型载体基础上, 首先开发出FH-UDS 高 HDS活性催化剂, 并在工业装置上得到广泛成功应用.

\section{3. 催化剂表面控制技术平台的开发}

由于4,6-DMDBT加氢的主要途径是先加氢饱和多 环芳烃后氢解脱硫, 因而需要催化剂具有适当的加氢性 能以满足多环芳烃的饱和. 当加工干点高的多环芳烃及 4,6-DMDBT含量较高的原料油时, 尽管FH-UDS催化剂 的活性金属含量明显高于其他同类催化剂, 但由于其加 氢性能不足, 使得超深度脱硫难度显著增加.

为了进一步改进FH-UDS 催化剂的超深度HDS 性 能, 深入研究了载体表面性质及活性金属与其加氢性能 之间相互关系, 发现载体表面的电子属性和化学性质、 浸渍液的理化性质等对金属的沉积速度、金属与载体的 结合程度都会产生明显的影响, 从而对催化剂金属的可 硫化性能、硫化后金属的价态及金属的分散稳定性产生 较大的影响 ${ }^{[13]}$.

在这些规律性条件考察的基础上, 建立起了一整套 调整载体与活性金属组分之间相互作用强弱的技术方 法, 掌握了催化剂表面控制技术. 采用该技术制备的催 化剂通过使用金属-载体有机针定剂等方法降低了金属 与载体间的相互作用.

采用该技术与传统方法分别制备的Mo-Co型催化 剂B和A硫化后的XPS表征结果列于表2. 由表可见, 催 化剂B中活性金属与载体间的结合能降低, 使得催化剂 更易于硫化, 且硫化后可生成更多理想的 $\mathrm{Mo}^{4+}$ 物种, 活 性金属硫化度也提高 $10 \%$ 以上, 从而有利于催化剂加氢 活性的提高.

在此技术平台基础上, 分别开发了高加氢活性的 W-Mo-Ni 型FHUDS-2 催化剂和直接脱硫活性好的 Mo-Co型FHUDS-3 催化剂. FHUDS-3 催化剂已在印度 IOCL 公司 78 万吨/年柴油加氢装置上实现长周期生产硫 含量 $<50 \mu \mathrm{g} / \mathrm{g}$ 产品的工业应用; FHUDS-2催化剂也应用 在国内多套柴油加氢装置中.

尽管FHUDS-2和FHUDS-3催化剂的HDS活性较高,
基本满足了工业装置生产国 IV 车用柴油的需要, 在一般 的条件下也能满足生产硫含量低于 $10 \mu \mathrm{g} / \mathrm{g}$ 柴油的生产 要求. 然而, 在加工条件比较苛刻时, 如反应空速较大、 反应温度要求较高、反应压力较低的条件下, 4,6-DMDBT类硫化物会因加氢反应途径受热力学平衡 的限制而难于彻底脱除.

\section{4. 改进催化剂烷基转移反应活性消除加氢脱硫 位阻效应的技术措施}

4,6-DMDBT脱除途径包括加氢、直接氢解脱硫和烷 基转移脱硫, 这取决于原料性质、液时空速和反应压力. 如果加氢途径是主要的, 应选用镍钼型催化剂; 如果直 接脱硫途径是主要的, 则应选用钴钼型催化剂. 加氢途 径的优点是反应活性高, 产品密度改进大, 但氢耗相对 较高, 并受反应热力学平衡的限制; 直接脱硫途径的氢 耗低, 而且可在较高的加权平均床层温度下操作, 但受 位阻效应的影响大; 而烷基转移途径则可以有效消除位 阻效应的影响, 温度提高反而更有利于烷基转移反应的 发生, 受热力学平衡限制影响小, 是高温下加氢途径受 热力学平衡限制时脱除4,6-DMDBT类大分子硫化物的 有效途径.

提高烷基转移反应活性的方法是适当增加催化剂 的酸性, 尤其是B酸含量. 但常规的酸性催化组分, 如分 子篮等将会增加产品的干气收率和氢耗, 因此, 通过添 加适宜的有机和无机助剂提高催化剂酸性, 开发了 B酸 显著增加的FHUDS-5 (Mo-Co) 和FHUDS-6 (Mo-Ni) 催化 剂, 高温时其烷基转移性能明显提高.

FHUDS-5催化剂与国外同类型参比催化剂的B酸及 $\mathrm{B} / \mathrm{L}$ 比的差异列于表 3 ; 以对二甲苯含量为 $1.43 \%$ 的混合 物为原料油, 考察了不同反应温度下对二甲苯含量的变 化以反映FHUDS-5 催化剂的烷基转移性能, 结果列于表 4.

由表3可见, FHUDS-5催化剂的B酸含量及B/L比显 著高于国外参比催化剂. 若以 $<250{ }^{\circ} \mathrm{C}$ 前脱附保留的酸 位为弱酸位, $>250^{\circ} \mathrm{C}$ 后脱附的酸位为中强酸位, 可以看 出, 该催化剂的中强 $\mathrm{B}$ 酸及 $\mathrm{B} / \mathrm{L}$ 比明显高于参比催化剂, 从而有利于提高催化剂较高温度下烷基转移性能, 因而 4,6-DMDBT的脱除主要按烷基转移路线进行.

由表4可见, FHUDS-5 催化剂烷基转移性能随反应 温度的升高而增加. 由于加氢装置生产超低硫柴油运转 的中后期反应温度较高, 特别是装填在反应器下部的催 化剂通常在较高温度下运行, 加氢反应途径往往受到热 
力学平衡的限制, 因而FHUDS-5催化剂的使用可有效消 除位阻效应和解除高温下热力学平衡限制, 从而有利于 4,6-DMDBT类硫化物的脱除.

图3比较了FHUDS-5 与国内外广泛认可的最新的 Mo-Co 型柴油超深度加氢脱硫催化剂的反应性能. 可以 看出, FHUDS-5催化剂在高温和超深度脱硫反应条件 下, 无其是在较低压力时具有更高的催化性能, 达到了 通过强化烷基转移反应以提高超深度加氢脱硫反应性 能的目的.

图4比较了系列FHUDS催化剂在超深度HDS (S < $10 \mu \mathrm{g} / \mathrm{g}$ ) 条件下的反应活性. 可以看出, 通过综合载体、 表面控制和反应路线控制等技术, Mo-Co型FHUDS-5催 化剂和Mo-Ni型FHUDS-6催化剂的性能明显改善. 其 中, FHUDS-5 催化剂于 2010 2011年间, 通过了挪威 STATOIL、英国 BP 及匈牙利 MOL等国外著名石油公 司评价体系的性能测试, 达到了世界一流催化剂水平. 2011年4月, 在欧洲某炼厂低压柴油超深度脱硫装置催 化剂换剂中与国外知名公司同台竞争中成功中标, 并实 现长周期生产超低硫柴油 $(\mathrm{S}<10 \mu \mathrm{g} / \mathrm{g})$ 的工业应用, 其 活性也优于前两个周期使用的国外同类型催化剂.

\section{5. 反应环境对柴油超深度脱硫的影响}

在研发和应用上述催化剂时发现, 在生产超低硫柴 油的条件下, 催化剂性能受多因素的影响, 如原料油中 氮化物含量以及较高温度下的热力学平衡限制等. 减少 不利反应环境对超深度脱硫的影响, 可促进加氢装置高 效运行和稳定生产超低硫柴油.

研究表明, 有机氮化物对HDS反应有强烈的抑制作 用 ${ }^{[14,15]}$. 其程度取决于氮化物的类型和浓度. 以吡啶为 例, 在 $340^{\circ} \mathrm{C}, 4.0 \mathrm{MPa}$ 和 $3.0 \mathrm{~h}^{-1}$ 反应条件下, 不同浓度氮 化物下苯并噻吩 (DBT)及 $4,6-\mathrm{DMDBT}$ 脱硫反应的途径 列于表 5. 可以看出, 氮化物的存在对加氢反应途径有抑 制作用; 氮化物含量较高时对直接脱硫路线(DDS)的影 响相对较小, 但显著抑制了 4,6-DMDBT的加氢步骤反应 速率及其脱除. 但当氮化物小于 $100 \mu \mathrm{g} / \mathrm{g}$ 时, 对加氢路 线(HYD)的影响并不明显.

4,6-DMDBT类硫化物由于甲基取代基位阻效应的 影响, 因而其脱除的主要途径是先加氢后氢解脱硫途径, 即多环芳烃加氢饱和消除位阻效应后再氢解脱硫, 但在 较高的反应温度下受热力学平衡的限制, 因而不利于加 氢途径的反应. 不同压力和温度条件下芳烃加氢反应结 果列于图5. 尽管不同压力下出现热力学平衡点温度不
同, 但超过热力学平衡限制后, 多环芳烃增加, 表明温度 过高会显著抑制4,6-DMDBT加氢反应途径的进行, 因而 高温不利于加氢为主要途径的脱硫反应, 从而影响超深 度脱硫效果.

如上文所述, 高温下不利于通过加氢途径以实现超 深度脱硫, 但有利于烷基转移途径的HDS反应. 众所周 知, 反应系统中 $\mathrm{H}_{2} \mathrm{~S}$ 含量影响HDS 反应的进行. 一般来 说, $\mathrm{H}_{2} \mathrm{~S}$ 含量越高, 反应活性越低. 低含量 $\mathrm{H}_{2} \mathrm{~S}$ 对加氢路 线的脱硫影响较小, 对直接脱硫路线的抑制作用更明显 一些; 但含量高时, 对加氢路线的脱硫影响较为明显, 而 对直接脱硫路线的抑制较小.

不同HDS催化剂受反应条件的影响不同, 这主要源 于催化剂对HDS反应路线的选择. 一般来说, Mo-Co型 催化剂以直接脱硫为主, 而Mo-Ni或W-Mo-Ni型催化剂 则以HDS为主. 因此, Mo-Co型催化剂直接脱硫活性高, 生产超低硫柴油时氢耗较低, 而且受热力学平衡影响小, 可在较高的加权平均床层温度下操作, 但该途径受位阻 效应的影响大, 可提高其烷基转移反应活性; 而 Mo-Ni 或W-Mo-Ni型催化剂的加氢脱氮和芳烃饱和活性高, 产 品密度改进大, 但受热力学平衡的限制, 低压和高温不 利于催化剂加氢性能的发挥.

对于柴油的超深度加氢脱硫, 根据反应环境选择合 适的催化剂非常重要. 当反应原料的氮含量和芳烃含量 较高, 而硫含量不太高, 反应压力较高, 且空速和温度不 太高时, 应该选择以HDS路线为主的催化剂; 相反, 则应 选择以直接脱硫路线为主的催化剂, 且这类催化剂应具 有较好的烷基转移反应活性. 多数情况下, 超深度加氢 脱硫反应环境介于这两种情况之间, 且在反应器入口催 化剂所处的反应环境较接近前者, 而反应器出口催化剂 所处环境则比较接近后者, 此时将两种类型的催化剂级 配使用更为合理.

以直馏柴油掺兄 $5 \%$ 催化柴油及 $35 \%$ 焦化汽柴油混 合油为原料油, 使用催化剂级配对超深度HDS反应的促 进效果见表6. 结果表明, 在所面临的反应环境下合理的 级配催化剂达到了协同增效的效果.

进一步研究表明, 在高温低压反应条件下, Mo-Co 类催化剂的活性稳定性要优于Mo-Ni或W-Mo-Ni催化 剂. 综合上述分析, 结合加氢装置实际运行中不同反应 区域环境的差异, 为了保证加氢装置在较高反应温度下 处理硫氮含量较高的直馏柴油与二次加工柴油混合原 料油, 可将高加氢活性的催化剂装填在反应器上部, 即 使运行到中后期, 其反应温度通常也不会超过 $370{ }^{\circ} \mathrm{C}$, 因 
而有利于多环芳烃的饱和及氮化物的脱除; 直接脱硫活 性及烷基转移性能好的Mo-Co 型催化剂装填在反应器 下部, 可有效降低运行中后期较高温度下热力学平衡限 制的影响. 目前, 在总结大量实验数据的基础上, 建立了 柴油超深度加氢脱硫反应动力学模型, 形成了柴油超深 度加氢脱硫催化剂级配使用优化技术平台. 催化剂级配 技术已在上海石化、镇海炼化等四套大型工业装置上得 到了应用, 取得了非常好的超深度脱硫反应效果.

\section{6. 结论}

通过对柴油超深度脱硫反应机理和催化基础的深 入研究, 建立了柴油超深度加氢脱硫催化剂开发的技术 平台,包括新型氧化铝载体制备技术、催化剂表面控制 技术和提升高温下烷基转移性能的催化剂改性技术; 由
此开发了以FHUDS-5 和FHUDS-6催化剂为代表的系列 性能优异的催化剂, 并得到了广泛的应用和市场认可. 同时, 这一新催化剂开发技术平台也为同类和其它加氢 催化剂的进一步研发奠定了良好的技术基础.

通过研究不同类型催化剂与反应环境之间的关系, 建立了利用加氢反应器内不同区域反应环境差异而采 用不同类型催化剂的催化剂级配使用技术, 从而满足了 生产国 IV 及欧 $\mathrm{V}$ 标准柴油的需求, 对于充分发挥加氢装 置和加氢催化剂的效率、提高工业装置对原料的适应性 和延长运行周期都有着一定的促进作用.

虽然FHUDS系列催化剂具有较高的高温活性及稳 定性, 但低温活性尚需进一步改进. 应从理论上分析和 探讨催化剂中金属与载体间相互作用的机制, 以进一步 提高FHUDS类催化剂性能. 